\title{
Synthetic Phonics on the Development of Reading Aloud
}

\author{
Reka Roefika Novita Putri \& Zaitun \\ Universitas Muhammadiyah Jakarta, Indonesia \\ (rekaroefika@gmail.com)
}

\begin{abstract}
This study aims to know the effect of synthetic phonics on the development of students reading aloud skills. This study was conducted at State Junior High School 3 Babelan, Bekasi, Indonesia. This study used a quantitative method, true-research experimental design with one group pre-test and post-test. The population of this research is all 8th grade students, and for two classes of 8th grade were taken as the sample, where one class is experimental and the other is control with the total number of 72 participants. A pre-test and post-test were given to know whether synthetic phonics is effective. The obtained result of both tests from the two classes were compared. The findings showed that the lowest score in the experimental class was 71 while the highest was 89 . Meanwhile, the lowest and the highest score of control class were 62 and 75, respectively. The difference of the highest scores between that obtained in the experimental and that in the control class is 14, meaning that experimental class gained 14 scores. It can be concluded that synthetic phonics is effective in the development of students' reading aloud skills, this study recommends continuation using synthetic phonics to develop students' reading aloud skills.
\end{abstract}

Keywords: Synthetic phonics; reading aloud; Junior High School.

Reading is a kind of activity that people do in order to get information or to know something from printed materials such as books, newspapers, etc. According to Novita (2015:397), reading is one of important ways to improve language proficiency in English because it helps learners enlarge the English vocabulary and improve their writing. Reading as one aspect of the four language skills, plays an important role in language teaching.

In teaching and learning English, there are several problems that students faced when reading, such as insufficient vocabulary, linguistic understanding problem. One basic problem that students face is mispronunciation, which can be observed when reading aloud. According to Izzah \& Hadi (2018:36), reading in foreign language not only focuses on words interpretation but also becomes an intercultural exchange in all fields: social, professional, academic and personal. It means that reading is beyond translating unfamiliar words; it includes knowing new vocabulary and learning all aspects from writing until speaking, where reading becomes a first step. 
In teaching reading, teacher directly teaches students to understand the text and then teaches them how to read aloud the correctly. As stated by Adita, et al., (2014:1), EFL students often make errors on pronunciation while reading aloud the English text because they do not have enough time to practice and experience it. It means the learning in the classroom has given less experience for students to master the basic knowledge about the sounds of alphabets and how they are mixed with words.

Reading aloud offers opportunities for the study of the link between spelling and pronunciation, of stress and intonation, and of sound connected speech. Reading aloud is important for EFL/ESL readers, especially in their early stage of learning English. According to Adita, et al., (2014:5) one advantage of reading aloud is that students can reassess at any future while reading which can eventually improve their pronunciation.

Sahara, et al,. (2018:113) stated that reading aloud is verbalising the words while adhering into intonation, stress, pitch, inflection and present the language for conveying the author message. Huang, et al., (2010:149) posited that reading aloud is a kind of comprehensive practice of pronunciation. It allows learners to not only pronounce every word correctly but also apply suitable stresses, intonations and rhythms to words. Therefore, reading aloud is a very good pronunciation practice to make students read English words correctly. Additionally, EFL students should know techniques and spelling of words, which will be under discussion of synthetic phonics.

Phajane (2014:2) explained that phonics is a way of decoding written letter and spoken sounds. It is a method for teaching reading and writing English language by developing learners' phonemic awareness the ability to hear. Phonics has two types, i.e. analytical phonics and synthetic phonics.

As Johnston, et al., (2014:152) stated that analytical phonics refers to teaching of reading in which the phonemes associated with particular graphemes are not pronounced in isolation. It means analytical phonics emphasizes the initial sound. According to Retnomurti, et al., (2019:16), analytic phonics starts with children analysing sounds in words, i.e. children begins with words and pick them apart. For example the word of run taught first then says three sounds $r / \mathrm{u} / \mathrm{n} /$. After that the children says each sound and mingle with three sounds together. This rule works for short but is problematic for longer words and encourages guessing as an initial reading strategy.

On the other hand, Xiaojing, et al,. (2016:11) explained that synthetic phonics is method to teach students reading English word properly where words are broken down into smallest unit of sounds (phonemes). Synthetic phonics taught students the letter (graphemes) that represent these phonemes and also learn to blend them into words. At its simplest, students are taught to read the letters in a word such c-a-t (stand), and merge them to pronounce the word cat. Synthetic phonics often used to teach students reading because synthetic phonics learn about sounds and letter. The definition of synthetic phonics makes it better for reading alound than analytical phonics.

The following is to illustrate why synthetic phonics is important. Ayu Petreny is an Indonesian woman who got married to a Hungarian. Their son's name is Maad. Maad took his early education in a Singapore school. Once, Maad's teacher told Ayu that Maad was the only student who could not read and Ayu did not expect if in Singapore a 4-year old child is expected to be able to read. The teacher suggested Ayu to use a synthetic phonics to teach children reading. It is used because alphabet which students have learned are different sounds when the alphabet blended in words. Such difference often confuses students why alphabets are spelled differently when collected as a word. Ayu said that learning alphabet is unimportant when learning reading, because the sound of the alphabet different pronouncing in English language, example, Alphabet/c/ we pronounce 
/si/ but in sentence cat, alphabet /c/ we read $/ \mathrm{k} /$. This illustration states the importance of learning synthetic phonics because it teaches about how sounds of the letters when blended into words.

Synthetic phonics is important for students to learn reading aloud since early, because it helps them to know about letters and facilitate them to learn reading aloud correctly. Phajane (2014:479) said that "[s]ynthetic phonics helps beginning readers understand how letters are linked to sounds (phonemes) to form letter-sounds correspondences and spelling patterns and to help students learn how to apply in their reading". Learning synthetic phonics also has an advantage, such as enabling students to correct their pronunciation while reading, develop their reading aloud, and become more confident in speaking the target language.

\section{Method}

In this study, the writer used a quantitative research method and trueexperimental as design. According to Creswell (2012:13), quantitative is analysing, comparing groups or relative variables using a statistical analysis, and interpreting results by comparing them with prior predictions and past research. The research was conducted at State Junior High School 3 Babelan. The writer used trueexperimental design and applied one group pre-test and post-test. True-experimental design required two classes, the first class was assigned as an experimental class and the second was as a control class.

The population is all students of 8th grade, and two classes were taken as samples. To decide the sample, the writer used a cluster random sampling, using the lottery method of sampling. In this sampling technique, the writer wrote name of class VIII-1 until VIII-9 on a piece of paper then put them into bottle and shook the bottle twice. One roll of paper was taken out at a time. The writer got VIII-1 for the experimental class and VIII- 6 for the control class. The number of students in both classes are equal; 37 . Therefore, 72 students were taken as samples.

For the research instruments the writer gave two kinds of test, namely pre-test and post-test. The purpose of pre-test is to know the entry achievement of students' before the experiment was conducted, and the purpose of post-test is to find out the differences of students' reading aloud achievements after treatment was given.

The pre-test and post-test were employed to determine whether Synthetic Phonics method become an effective method to students' in developing reading aloud skills. To determine the hypothesis of the study, the Kolmogorov Smirnov test (used in a normal distribution) and the Levene test (used to analyze homogeneity of variance test) were conducted. Finally, to determine the significant difference between two group' means, the t-test was selected.

\section{Results and Discussion}

In research was conducted from March until April 2020. The writer used pre-test and post-test to know whether synthetic phonics is effective for developing students' reading aloud skill.

The pre-test which was given before the treatment yielded the result as shown in Figure 1. The diagram tells that the result from the two classes the lowest score is 60 , the highest score of the experimental class is 75 and that of the control is 72 . The difference in value between the two classes is 3 , meaning that the ability in reading aloud of two groups of students before the treatment was given was equal.

To know if the synthetic phonics is effective or not the writer implemented synthetic phonics as method to develop students' reading aloud skill in the experimental class, while the control class was given a common method to develop their reading aloud skill. Before giving students the treatment in the experimental class, the writer gave students pre-test, whose 


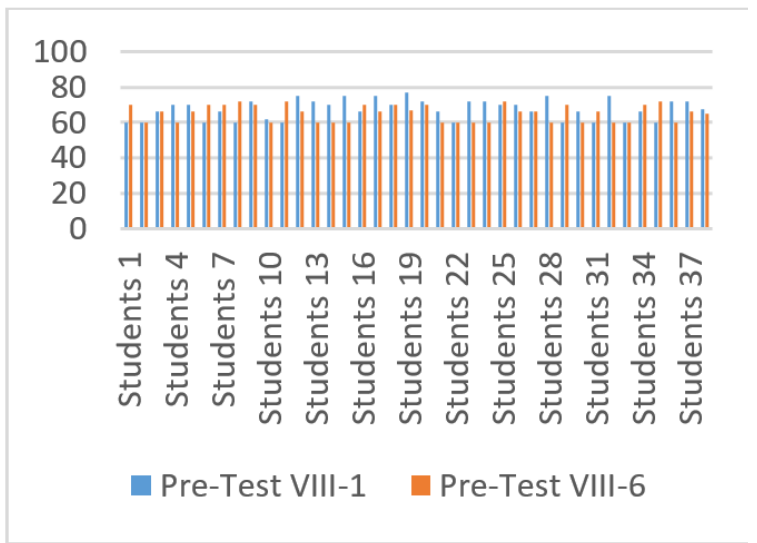

Figure 1. The pre-test scores of the experimental \& control class

purpose is to know the student achievement before the writer started teaching the students. In the pre-test, the writer asked student to read a text, one student read one paragraph then the score was analyzed for getting the result, it can be seen in Figure 1.

The finding revealed problems which occurred in reading aloud, such as incorrectly pronouncing and spelling the words. Students did know how to pronounce the new words correctly, have not enough time to practice reading aloud, most of students are weak in pronunciation, spell the words and phonemic awareness. These issues greatly impacted their success in learning, particularly in reading aloud.

For the post-test the writer asked students to read the same text as that of the pretest. When one student read one paragraph, he/ she should record it and upload it to a social media (Instagram feed) and tag the writer's account, students should show the creativity on the video, as Hadi \& Izzah (2019:150), it is unquestionable that technology has changed the educational world view from ordinary to computerized models: explicitly through the use of information technology (IT). It means we should utilize for education and fittest with students gen $Z$, after the writer examined the video which students have uploaded, the writer assessed their video while reading aloud the text. The result can

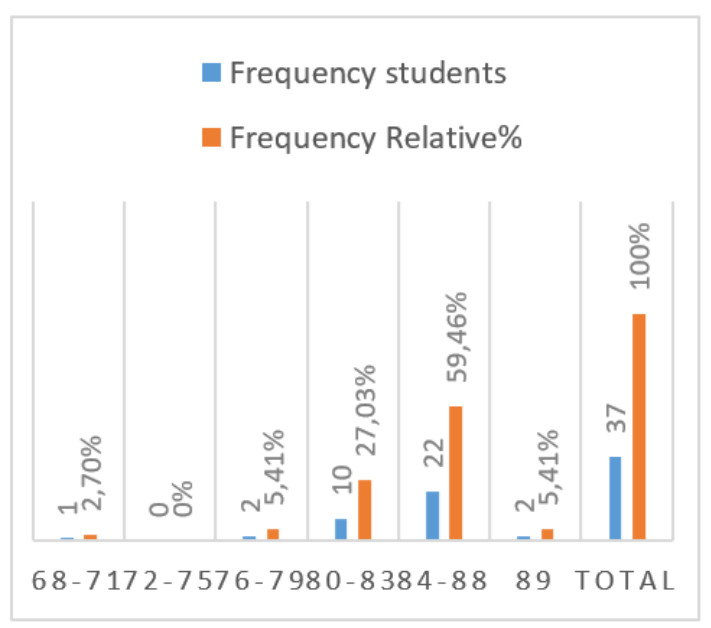

Figure 2. The post-test scores of the experimental class

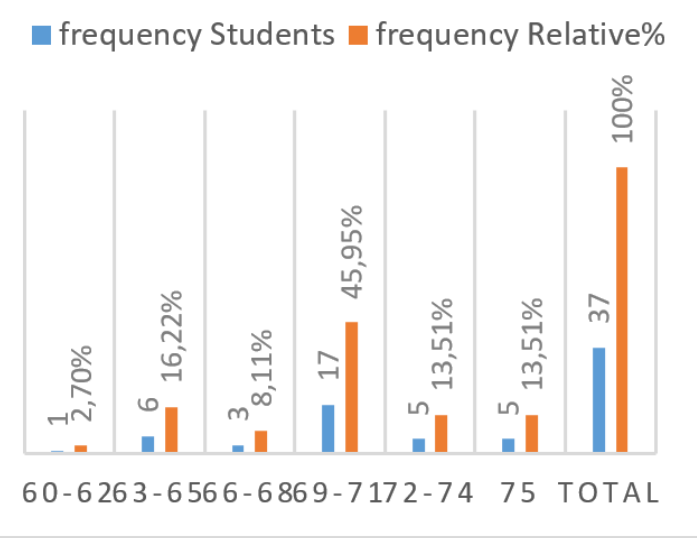

Figure 3. The post-test scores of the control class

be seen in the diagram in Figure 2.

The diagram above displays the result obtained from the experimental class. One student $(2.70 \%)$ got $68-71,0$ student $(0 \%)$ got 72-75, $2(5.41 \%)$ students got 76-79, 10 students $(27.03 \%)$ got $80-83,22$ students (59.46\%) got $84-88$, and 2 students $(5.41 \%)$ got 89 .

Based on the diagram of the control class above, obtained the following. One student (2.70\%) got 60-62, 6 students (16.22\%) got 63 65,3 students $(8.11 \%)$ got $66-68,17$ students (45.95\%) got $69-71,5$ students $(13.51 \%)$ got 72-74, and 5 students (13.51\%) got 75 .

To check whether the post-test scores of both groups were normally distributed, the Kolmogorov Smirnov test was used. The result is presented in Table 1. 
Table 1. Normality Test

\begin{tabular}{lr}
\hline & \multicolumn{1}{c}{ Data } \\
\cline { 2 - 2 } N & 74 \\
Mean & 76.74 \\
Std. Deviation & 8 \\
Absolute & 0,142 \\
& \\
Kolmogorov-Smirnov Z & 0,158 \\
\hline
\end{tabular}

Table 2. Homogeneity of Variances Test

\begin{tabular}{lll}
\hline & Variable 1 & Variable 2 \\
\cline { 2 - 3 } Mean & 83,7027027 & 69,7837838 \\
Variance & 17,71471471 & 12,5630631 \\
Observations & 37 & 37 \\
Df & 36 & 36 \\
F & 1,410063344 & \\
P(F<=f) one-tail & 0,153559441 & \\
F Critical one-tail & 1,742973165 & \\
\hline
\end{tabular}

The score of Kolmogorov Smirnov (Dmax) with $\mathrm{N}=74$ in significance $\alpha=0.05$ was 0.158 higher than the significant level (0.142). Obviously, the scores of both classes were normally distributed. The Levene test was used to analyze homogeneity of variance scores of the both class, the result of the Levene test is available in Table 2.

From Table 2 above, the value of homogeneity (F) in post-test was 1.410063344 , it means the data was homogeneous because the value of $F$ critical one-tail was bigger than value of $F$. it can be said homogenous if ( $F$ $<\mathrm{F}$ Critical one tail) and the result showed
$1.410063344(\mathrm{~F})<1.742973165$ (F Critical one-tail). Therefore, it can be concluded that the control and experimental class variances are homogenous.

Based on Table 3, the writer got to conclude that the experimental class has 37 students with a mean of the post-test score is 83.7027 , and the standard deviation of the experimental class is 4.20888. Meanwhile, the statistic of the control class also has 37 students, mean of the post-test scores of control class is 69.7837, and the standard deviation of the control class is 3.54444. (4.20888 > 3.54444) so that variation distance of the experimental class data is larger than the control class has. After that, the t-test was conducted to investigate whether there were significant differences between the experimental class and the control class. The hypotheses set out in this analysis were in the form of a null hypothesis and alternative hypothesis.

As seen in Table 4, the result showed that the $\mathrm{t}$-test ( $\mathrm{t}$ Stat) was higher than $\mathrm{tt}(\mathrm{t}$-table), the value of $\mathrm{df}$ (Degree of freedom) is 72 at degree of significance $5 \%$ or $\mathrm{tt}$ ( $\mathrm{t}$-table) is 1.666293696 . The result is $15.3866604>1.666293696$. It can be interpreted that synthetic phonics is effective to develop students reading aloud skills. Therefore, the null hypothesis ( $\mathrm{H} 0)$ was rejected. It can be said, the averages of both class were significantly different. In other words, the treatment was implemented in the experimental class significantly developed the students' reading aloud skills.

\section{Conclusion}

Table 3. Group Statistic

\begin{tabular}{llllll}
\hline \multirow{3}{*}{ Post-test } & Class & $\mathrm{N}$ & $\mathrm{Mean}$ & Std. Deviation & Std. Error Mean \\
\cline { 2 - 6 } & Experiment & 37 & 83.7027 & 4.20888 & 0.69193 \\
& Control & 37 & 69.7837 & 3.54444 & 0.58270 \\
\hline
\end{tabular}


Table 4. t-Test: Two-Sample Assuming Equal Variances

\begin{tabular}{lrr} 
& \multicolumn{1}{c}{ Experimental Class } & Control Class \\
\cline { 2 - 3 } Mean & 83,7027027 & 69,78378378 \\
Variance & 17,71471471 & 12,56306306 \\
Observations & 37 & 37 \\
Pooled Variance & 15,13888889 & 0 \\
Hypothesized Mean Difference & 72 \\
Df & 15,3866604 \\
t Stat & $9,22106 \mathrm{E}-25$ \\
P $(\mathrm{T}<=$ t) one-tail & 1,666293696 \\
t Critical one-tail & $1,84421 \mathrm{E}-24$ \\
$\mathrm{P}(\mathrm{T}<=\mathrm{t})$ two-tail & 1,993463567 \\
t Critical two-tail & & \\
\hline
\end{tabular}

The implementation of synthetic phonics for teaching reading aloud skills at Junior High School of 3 Babelan, Bekasi Indonesia is effective and can develop students' reading aloud skills. The effect of synthetic phonics can be seen from the difference scores between the post-test scores of the experimental class and control class, which the scores of the experimental class is higher than scores of the control class. The effect of synthetic phonics method in teaching reading aloud also solves students' problem such as mispronounce when reading aloud the English text. This research is one of the alternative way that can be used by the teacher to teach students' reading aloud.

In this study, other findings showed that students in experimental class had better performance in reading aloud than Control class. They showed the progress in reading aloud the English text, they improve their stress, pronunciation, and spelling the words while reading aloud. And the result of t-test showed that there was significant difference between the means of the experimental class and those who were in the control class. Therefore, the null hypothesis (H0) was rejected, it means that the treatment that has given to the experimental class is significant to develop the students' reading aloud skills. Hopefully, this learning and knowledge are useful for developing students in mastery reading aloud.

\section{References}

Adita, A.K., Bindarti, W. E., \& Wahyuningsih, E. (2014). The use of reading aloud technique to improve the VIII-A grade students' pronunciation achievement in reading narrative text at SMPN 1 Situbondo, 1-9.

Creswell, John W. (2012). Educational research, planning, conducting and evaluating qualitative and quantitative research. Boston: PEARSON

Hadi, M.S., \& Izzah, L. (2018). Problem based learning $(\mathrm{PBL})$ in teaching English for students of primary school teacher education department. English Language in Focus, 1(1), 44-45.

Hadi, M.S., \& Izzah, L. (2019). Engaging learners with interest of thing (IOT): Gen Z'S perspective. Educational initiative research colloquium, 150.

Huang, Liangguang and Zhenjiang. Reading aloud in the foreign language teaching. Asia Social Science. 4(6), 148-150.

Izzah, L \& Hadi, M.S. (2018). Systematic functional genre on students' reading literacy. English Language in Focus. 1(1), 35-44.

Johnston, Jane \& Cindy Nahmad W. 2014. Early childhood studies. New York: Routledge. 
Novita, P. (2015). The effect of students' perception on teacher's performance and learning style towards student's reading comprehension. International Conference on Social Science Research, 397-404.

Phajane, M. H. (2014). Introducing beginning using phonics approach. Mediterranean Journal of Social Sciences, 5(10), 477-483.

Retnomurti.A, N. Hendrawaty \& N. Nurhayati. (2019). Introduction strategy to read phonics method in community service in South Jakarta. JJP IPTEK, 3(1), 1-20.

Sahara, Bahri \& Erdiana. (2018). The use of reading aloud in teaching reading comprehension. Research in English and Education, 3(2), 112-117.

Xiaojing, L. Junying, Z. \& Jing, H. (2016). A case study of phonics among primary school students. International Journal for Innovation Education and Research, 4(10), 11-16. 